\title{
THE INFLUENCE OF PROFITABILITY AND ACTIVITY RATIOS ON THE SHARES MARKET PRICE OF THE PUBLIC BANK COMPANIES IN INDONESIA
}

\author{
Bambang Hadi Santoso Dwidjosumarno \\ STIESIA Surabaya-Indonesia \\ Bambanghadisantoso@stiesia.ac.id
}

\section{A R T I C L E I N F O}

Article history:

Received : 10 April 2019

Revised : 23 April 2019

Accepted : 23 May 2019

Key words:

ROA, ROE, ROI, shares market prices, public bank companies

DOI:

https://doi.org/10.33508/rima.v2i1.2598

\begin{abstract}
A B S T R A C T
The purpose of the study is to examine the influence of the ratios of ROA, ROE and ROI altogether and each of them and the shares market price of public bank companies in Indonesia during 2012-2017. ROA and ROE ratios on this study are regarded as the proxy of profitability ratios, while, ROI ratio on this study is considered as the proxy of activity ratio. Based on the study result, it shows that all ratios have a positive relationship with the shares market price of public bank companies in Indonesia. The results exhibit that each ROE and ROI has a positive relationship with the shares market price of public bank companies in Indonesia. However, it is inconsistent with ROA that it found that there is no relationship between ROA and the shares market price of public bank companies in Indonesia.
\end{abstract}

\section{INTRODUCTION}

The financial ratio can be defined as a relationship between two individuals with quantitative financial information connected to each other in some logical manner. This kind of connection is considered as a meaningful financial indicator which can be used by the different financial information users. Any financial ratios might be meaningful and useful information, both for present or past similar indicators for the same or similar firm in same industry. Although financial ratios are considered practical and useful in financial analysis, these financial ratios should be interpreted and analyzed in a rational manner with caution taken into consideration, such as the limitations of these financial ratios for the purpose of obtaining the expected meaningful result from it.

The ratios of profitability are an indicator for the company's overall efficiency. It is usually applied as a measure in earning generation by the company during a period of time based on its level of assets, capital employed, net worth, sales and EPS (Earning Per Share). Ratios of profitability measure earning capacity of the company and it is considered as an indicator for its growth, success and control. For example, the investors of shares are interested in profitability ratios, because this will indicate the progress, as well as the rate of returns from the investments. And then, the creditors are also interested in the ratios of profitability, because this will indicate the capability of a company to meet the obligations of interests.

There are three types of financial ratio. Firstly, ROA (Return on Assets) ratio which is calculated as the net profit after taxes divided by total assets. This ratio measures the company's operating efficiency based on the company's generated profits from its total assets. Secondly, ROE (Return on Equity) or return on owner's ratio. This ratio is calculated as net profit after taxes divided by total shareholders' equity. This ratio 
measures the shareholders' rate of return on their investment in the company.

The last is another group of ratios called activity ratios. The activity ratios are usually applied in order to measure the ability to optimize the use of the resources available in the company. Such ratios calculate the operational efficiency and effectiveness. One of these ratios is ROI (Return on Investment) ratio. ROI ratio is calculated as net profit after taxes divided by total paid in capital. ROI determines the company's efficiency and effectiveness to utilize the invested capital or, in other words, ROI ratio expresses the company's ability to generate the expected return (required return) by employing and managing the invested resources by shareholders.

Financial ratios which are calculated from financial statement are the oldest, simplest and practical financial and planning analysis tools. Financial ratios appeared in $19^{\text {th }}$ century and are always used by financial analyst, internal and external data users in in order to make their economic decisions, including investment decisions, as well as the performance evaluation decisions. Many financial models have already developed during the past decades.

However, the financial ratios keep its classical and fundamental power, either as part of these financial models or as another important supporting analysis. Proven as a strong ratio analysis in the practical financial and planning analysis, this study aims to explore the effects and the power for ROA, ROE and ROI ratios altogether and each of them in explaining the stock prices within the periods of 2012-2017 for one of the most important sectors in Indonesia. It is expected that this study is able to fulfill to the shortage of studies in this important area.

\section{LITERATURE REVIEW AND HYPOTHESES}

Hutapea et al. (2017) studied the influence of ROA (Return on Asset), NPM (Net Profit Margin), DER (Debt Equity Ratio) and TATO (Total Asset Turnover) against the share prices of an automotive components and industry in the Indonesia Stock Exchange. They concluded that partially only DER and TATO which have a significant effect on share price, while, ROA and NPM are not significant to share price. Simultaneously ROA, NPM, DER and TATO affect share price of automotive components industry in Indonesia Stock Exchange.

Meanwhile, Rutika et al. (2015) also examined the impact of EPS (Earning Per Share), NPM, ROA and DER to the share prices of insurance companies listed in Indonesia Stock Exchange from 2011 to 2013. The result of their partial hypothesis test showed that EPS has a positive influence toward the share price. The study also found if NPM does not have any ability to change or affect the share price, consequently, ROA and DER does not have any ability to explain the share price partially. Furthermore, it also found that that EPS, NPM, ROA and DER has a positive influence toward the share price.

Moreover, Shanab (2008) examined the influence of returns and risks on the share prices from 38 industrial companies as the samples in Jordan on Amman Security Exchange during the period of 2000-2007. The results showed that there is no any effect for the returns, risks and dividends on the market value per share. However, it indicated that there is a significant relationship between cash flow and share prices. Along with that, Kurdi (2005) explored the ability of published information on accounting to estimate the share prices from a number of representative samples from 110 Jordanian public companies listed in Amman Security Exchange during 19942004. It stated that there is a relationship between the published information on accounting of the public insurance companies and the share prices. Furthermore, it also exhibited that if compared to accounting information, the market information has more ability in predicting the share prices.

A research by Qudah in 2004 tested the 
role of accounting exposure in indicating the real market price. The sample of the study was compiled from 35 public companies listed in Amman Security Exchange, 23 licensed financial traders, and 27 investors at the exchange. It concluded that the revealed financial data of public companies are sufficient and appropriate in showing the values of real share using the study samples which were categorized based on a different mechanism in their investment decisions of investors by compiling economic information as well as financial information.

While Hasheesh in 2003 focused on the role of published accounting information to predict the share prices. Hasheesh employed 40 Jordanian public companies listed in Amman Security Exchange in 2003 as the samples. The result showed that there is a positive significant relationship between the shares market price with the net profit to equity ratio, net profit to total assets ratio, and dividends to net profit ratio as a total. It also revealed a negative significant relationship between the market price for each share with fixed assets to total assets ratio, the creditors total to total of cash sources ratio, and also the wages ratio to total of expenses ratio.

Furthermore, Thaher (2003) in his study examined the influence of dividend policy on the shares market prices. It was used samples from 7 Jordanian commercial banks listed in Amman Security Exchange during the periods of 1996-2000. The results of the study indicated a positive significant relationship between the market price per share with dividends and this result varies between the each sampled banks.

Aside from those studies above, Khalaileh in 2001 also studied about the relationship between accounting performance indicators and market performance indicators with the samples from 40 Jordanian public companies listed in Amman Security Exchange during the periods of 1984-1996. The results of the study explained a positive significant relationship between the market price per share with the ROA ratios and ROE ratios.
Based on the above literature review, it is underlined that some of previous studies found several relationships between the market price per share and several financial ratios. Thus, this study formulated these following four hypotheses below:

$\mathrm{H1}$ : There is a significant statistical relationship between ROA ratio, ROE ratio, as well as ROI ratio together with the shares market price of public bank companies in Indonesia.

$\mathrm{H} 2$ : There is a significant statistical relationship between ROA itself with the shares market price of the public bank companies in Indonesia.

H3: There is a significant statistical relationship between ROE ratio itself with the shares market price of public bank companies in Indonesia.

H4: There is a significant statistical relationship between ROI itself with shares market price of public bank companies in Indonesia.

\section{METHODOLOGY}

The study was designed as a quantitative research. A quantitative research design in this research emphasized on the theory testing thorough its research variables measurement by using figures, by conducting data analysis through statistical procedures, as well as by interpreting of result analysis.

\section{Models of the study}

The models of the study are in the following: $\mathrm{MPS}=\mathrm{a}+\mathrm{b} 1 \mathrm{ROA}+\mathrm{b} 2 \mathrm{ROE}+\mathrm{b} 3 \mathrm{ROI}+\mathrm{e}$ (i)
MPS $=\mathrm{a}+\mathrm{b} 1 \mathrm{ROA}+\mathrm{e}$
(iii)
MPS $=\mathrm{a}+\mathrm{b} 1 \mathrm{ROI}+\mathrm{e}$
(iv)
In which:
MPS : Market Price/Share
a : Constant
ROA : Return on Asset
ROE : Return on Equity
ROI : Return on Investment

MPS $=\mathrm{a}+\mathrm{b} 1 \mathrm{ROE}+\mathrm{e}$ 
$\begin{array}{ll}\text { b1-b3 } & \text { : Coefficients of the variables } \\ \text { e } & \text { : residual }\end{array}$

Population and sample of the study

The population of the study comprised all public bank companies listed in Indonesia Stock Exchange from 2012 and 2017 which were 42 public companies. There were 8 public bank companies are excluded, because the data is not available. Therefore, the total number of sample was equal to 34 public bank companies listed on the Indonesia Stock Exchange. Financial and market data were obtained from the 2018 Annual Statistics of Indonesia Stock Exchange.

\section{RESULT AND DISCUSSSION}

The result and discussion are based on statistical analysis and testing of hypotheses.

Table 1: Descriptive statistics

\begin{tabular}{|l|l|l|l|l|l|}
\hline & $\mathrm{N}$ & Min & Max & Mean & Std Dev \\
\hline ROA & 204 & -11.73 & 38.60 & 1.0946 & 3.39496 \\
\hline ROE & 204 & -82.62 & 73.10 & 7.0433 & 16.28637 \\
\hline ROI & 204 & -2.42 & 18.24 & 1.2792 & 3.26972 \\
\hline MPS & 204 & 50.00 & 21,900 & 1,988 & 3,257 \\
\hline
\end{tabular}

Table 1 presents the statistical summary for all variables of the study. The market price is reported in Rupiah currency (Indonesia currency). The above table shows that the shares price of public bank companies in Indonesia is IDR 1,988 with the maximum value of shares price is IDR 21,900 and the minimum value is IDR 50 .

This indicates that the shares price of bank public companies in Indonesia are very fluctuated with the high standard deviation value of $3,257.13$. The average of ROA ratio at the in the public bank companies in Indonesia is $1.0946 \%$ with the maximum value of ROA ratio is $38.60 \%$, and the minimum value of ROA ratio is $-11,73 \%$. This data indicates that ROA ratio of public bank companies in Indonesia owns a great difference with the standard deviation value of $3,395 \%$. While, the average ROE ratio of public bank companies in Indonesia is 7.0433 or $7.043 \%$ which means that the average public bank companies in Indonesia have the rate of return from the use of equity is equal to $7.0433 \%$.

Furthermore, this data also indicates that ROE of public bank companies in Indonesia owns a great difference with the value of standard deviation is $16.29 \%$. From Table 1, it is known that the average of ROI ratio of public bank companies in Indonesia is 1.2792 or $1.28 \%$ and this shows that the average public bank companies in Indonesia, the return on investment is $1.28 \%$ with the maximum value of ROI ratio is $18.24 \%$ and the minimum value of ROI is $-2,42 \%$. This data indicates that ROI ration from public bank companies in Indonesia is a great difference with standard deviation value of $3.27 \%$.

\section{Multiple linear regression analysis}

The analysis of multiple regression is performed based on the data available in Table 2 which presents the regression result and Table 3 which shows the R, R2 (R square), and $\mathrm{F}$ test.

Table 2: The regression result

\begin{tabular}{|l|l|l|l|l|}
\hline Variables & Coeff & B & t & Sig. \\
\hline ROA & -18.433 & -0.019 & -0.276 & 0.783 \\
\hline ROE & 36.121 & 0.181 & 2.534 & 0.012 \\
\hline ROI & 519.446 & 0.521 & 8.757 & 0.000 \\
\hline
\end{tabular}

Table 3: The $R, R 2$ ( $R$ square), and $F$ test

\begin{tabular}{|l|l|}
\hline$R$ & $=0.593$ \\
\hline R2 (R square) & $=0.352$ \\
\hline F test & $=36,176$ \\
\hline Significance & $=0.000$ \\
\hline
\end{tabular}

The multiple linear regression is shown below:

MPS $=1,089.430-18.433 \mathrm{ROA}+36.121 \mathrm{ROE}$

$+519,446 \mathrm{ROI}+\mathrm{e}$.

\section{Interpretation of multiple linear regression mode1}

Constant and coefficient of regression

The constant value is $1,089.430$. If ROA, ROE and ROI ratios values is equal to 0 ; this means that the price of public bank 
companies in Indonesia is IDR 1,089.430.

The coefficient of regression for ROA ratio is -18.433 (see Table 2). This means that, if $\mathrm{ROA}$ ratio increases, the shares price of public bank companies in Indonesia will decrease $18.433 \%$; and if ROA ratio decreases, the shares price of public bank companies in Indonesia will increase $18.433 \%$ with the assumption that the values of ROE and ROI ratios are constant.

The coefficient of regression for ROE ratio is 36.121 (see Table 2). This shows that if $\mathrm{ROE}$ ratio increases, the shares price of public bank companies in Indonesia will increase $36.121 \%$; and if ROE ratio decreases, the shares price of public bank companies in Indonesia will decrease $36.121 \%$ with the assumption that the values of ROA and ROI ratios are constant.

The coefficient of regression for ROI ratio is 519.446 (see Table 2). This means, if ROE ratio increases, the shares price of public bank companies in Indonesia will increase 519.446\%; and if ROE ratio decreases, the shares price of public bank companies in Indonesia will decrease $519.446 \%$ with the assumption that the values of ROA and ROE ratios are constant.

Interpretation of multiple linear regression model Coefficient of determination

The coefficient of determination is calculated as 0.352 or $35.20 \%$ (see Table 2). This exhibits that the shares price of public bank companies in Indonesia is able to be explained by the independent variables of ROA, ROE, and ROI, and the remained $64.80 \%$ is explained by other variables.

\section{F test}

The result of $F$ test of the regression is 36,176 ; it means that ROA, ROE, and ROI variables influence simultaneously with the shares price of public bank companies in Indonesia with the significance value of $0.000<$ significance level of $0.05 \%$.

Testing of hypotheses

ROA, ROE and ROI
Based on the calculation as seen in Table 2 , the significance value for ROA is $0.783>$ 0.05 . It means that ROA has no negatively significant influence with the shares price of public bank companies in Indonesia. Significance value for ROE is $0.012<0.05$. It shows that ROE has positively significant influence to the shares price of public bank companies in Indonesia. Meanwhile, significance value for ROI is $0.0000<0.05$. This indicates that ROI has positively significant influence with the shares price of public bank companies in Indonesia.

\section{CONCLUSION}

The result of the study showed a positive relationship between ROA, ROE and $\mathrm{ROI}$ ratios altogether with the share market price of public bank companies in Indonesia. It also states that each of ROE ratio and ROI ratio has a positive relationship with the share market price of public bank companies in Indonesia. In contrast, it reveals that there is no any relationship between ROA ratio and the share market price of public bank companies in Indonesia.

\section{REFERENCES}

Hasheesh, K. A. 2003. The Role of Published Accounting Information in Predicting of Stock Prices, An Applied Study on Listed Corporations on Amman Stock Exchange, Al Basa'er Magazine, Petra University, Amman, Issue 2.

Hutapea, A. W., Ivonne, S. S., Joy, E T. 2017. Influence of Return on Assets, Net Profit Margin, Debt Equity Ratio, Total Asset Turnover against Stock Price the Automotive Industry and Components in the Indonesia Stock Exchange", Journal EMBA, Vol. 5, No. 2.

Khalaileh, M. 2001. The Relationship between Accounting Performance Indexes and Market Performance Indexes", An Applied Study on Listed Corporations at Amman Security 
Exchange. Administrative Sciences Studies Magazine. Jordan University, Amman, Issue 1.

Kurdi, A. 2005. The Ability Range of Published Accounting Information on Stock Prices Prediction: An Applied Study on Public Shareholding Corporations on Amman Security Exchange. Unpublished Doctorate Thesis, Arab Academy for Financial and Banking Sciences, Amman, Jordan.

Rutika, A, M,. 2015. Analysis the Influence Earning Per Share, Net Profit Margin, Return on Asset and Debt To Equity Ratio against Share Prices the Insurance Companies Listed in Indonesia Stock Exchange Year 2011-2013 (Case Study at the Insurance Companies Listed in the Indonesia Stock Exchange), Jurnal Ilmiah Akuntansi Bisnis \& Keuangan STIE-IBEK.

Shanab, A, S. 2008. The Impact of Returns and Risks on Share Prices: An Applied Study on Industrial Corporations Listed at Amman Stock Exchange. Unpublished Doctorate Thesis, Arab Aman University for Higher Studies, Amman, Jordan.

Taher, M. 2003. Profits Distribution Policy and its Impact on the Market Stock Price, An Applied Study on One Sample of Commercial Banks at Amman Security Exchange. Bettlehem University Magazine, Bettlehem, issue 22.

Qudah, Y. M. 2004. The Role of Accounting Revelation in Showing the Real Market Value of Exchanged Corporations' Stocks in Amman Security Exchange. Unpublished Thesis, Arab Amman University, Amman, Jordan. 